\title{
Assessment of Factors Affecting Audit Quality: "A Study of Selected Companies Listed on the Ghana Stock Exchange"
}

\author{
John Kwaku Mensah Mawutor (Corresponding author) \\ Dean, School of Graduate Studies \\ University of Professional Studies, Accra \\ P.O. Box 149, Legon, Ghana \\ Tel: 23-3243-287-242Ｅ-mail: john.mensah@upsamail.edu.gh \\ Borketey-La Francis B \\ University of Professional Studies, Accra \\ P.O. Box 149, Legon, Ghana \\ Asamoah Douglas Obeng \\ University of Professional Studies, Accra \\ P.O. Box 149, Legon, Ghana
}

Received: April 19, 2019

Accepted: May 29, 2019

Published: June 2, 2019

doi:10.5296/ijafr.v9i2.14692

URL: https://doi.org/10.5296/ijafr.v9i2. 14692

\begin{abstract}
This study sought to establish the factors affecting audit quality in listed companies in Ghana. A cross-sectional method was used in the analysis in which a linear regression model was also used to establish the impact of the independent variables namely; auditor size, the existence of audit committee and the logarithm of the auditor fees on the independent variable audit quality. The logarithm of audit fees was taken to normalize the data. The dependent variable "leverage ratio" (total debts divided by total assets of the company) used to measure debt pressure by the companies and also used as a proxy for the audit quality
\end{abstract}


because high debts in relation to company assets can lead to bankruptcy. Twenty- five (25) companies listed on the Ghana Stock exchange were used as the sample of the study. The results of the analysis indicated that logarithm of audit fees, existence of audit committee, and auditor size were all significant in influencing the leverage of the companies and thus audit quality. The size of audit firm had a negative impact on audit quality, while the companies that do not have audit committees are more likely to have poor audit quality. The logarithm of audit fees was positively related with the audit quality. It is recommended that audit fees should be regulated by The Institute of Chartered Accountants Ghana (ICAG) as well as taking action against audit companies which do not adhere to auditing standards and the officials of companies who are involved in misstating the financial statements and other financial records with the intention of concealing the true and actual facts of the financial position of the company.

Keywords: Audit quality, ICAG, Leverage ratio, Auditor size, Fees, Standard, Auditing

\section{Introduction}

The Report on the Observance of Standards and Codes, Ghana (2004), states that although Ghana has not yet experienced significant litigation against auditors, it appears that accounting and auditing practices in Ghana suffer from institutional weaknesses in regulation, compliance and enforcement of standards and rules. Full compliance with Ghana National Accounting Standards is not readily achieved; there is inadequate adherence to auditing standards and professional ethics. Keasey \& Wright (2012), on corporate accountability and governance postulated that shady directors were misappropriating shareholders' funds through lavish executive compensation, while focusing on short-term objectives as opposed to the long-term goals. The study further suggested enhancing of the perceived objectivity of the audit through rotation of auditors, directors' engagement terms limited to 3 years and the setting up of remuneration committees to determine executive pay.

The study conducted is, however, limited in some areas, specifically, it recognizes the limited role of audit in providing oversight, but a gap still exists as it does not provide a potent alternative means of regulating companies with more active shareholders involvement. There are still a number of issues that are surrounding audit, corporate governance and accountability. There is a need for users of financial statements to be protected so that they do not fall victim to fraudulent financial reporting. According to Grace \& Ambrose (2013), financial statements should be credible. The external users comprise of the government, investors as well as financial institutions. For instance, the government, uses financial statements to determine accurate assessment of tax payment while financial institutions rely on audited financial statements to decide whether to provide a company with credit or not. Investors on the other hand, depend on the audited financial statements to assess the financial strength of a company to aid in making informed decisions. It is in this regard that we conduct this study to look at the factors affecting audit quality in enhancing the accountability in the management of shareholders' funds and ways on how to restore confidence in the audit profession.

1. What are the factors that influence audit quality in some selected listed companies in 
Ghana?

2. What is the relationship between audit quality and audit committee in some selected listed companies in Ghana?

3. What is relationship between audit firm size and audit quality in some selected listed companies in Ghana?

4. What is the relationship between audit quality and audit fee in some selected listed companies in Ghana?

The main objective of the study is to investigate the factors influencing audit quality in listed companies on the Ghana stock exchange.

\section{Literature Review}

Audit quality is an important issue that is considered by various interest groups in the company, audit scope and capital market. Because audit quality is barely visible in practice, research in this area has always been faced with many problems of definition. One of the most common definitions of quality audit, which is defined by De Angelo (1981), is the assessment of the possibility that the auditor will detect significant distortions of the financial statements or employers accounting system and report significant these distortions. To meet the specific objectives of this study, the agency theory, theory of credibility, policeman theory and theory of inspired confidence used reviewed.

According to the Agency theory, Auditors act as agents to their respective clients when performing audits and this relationship therefore brings with it similar concerns with regard to trust and confidence as the director-shareholder relationship, prompting questions about who is auditing the auditor. Agents (whether they are directors or auditors) may be trustworthy without a need for further incentives to align interests or monitoring mechanisms such as audit or increased regulation. However, the simple agency model would suggest that agents are untrustworthy. Like directors, auditors will have their own interests and motives to consider. For example, auditors may be risk averse and being conscious of their potential liability, introduce risk management processes that result in limitations in the scope of their work and caveats in their reports which principals may find frustrating. Auditor independence from the board of directors is of great importance to shareholders and is seen as a key factor in helping to deliver audit quality. However, an audit necessitates a close working relationship with the board of directors of a company. The Shareholder demand tougher controls and standards over independence to protect them because there is a development of close relationship that has inspired shareholders to question the perceived and actual independence of auditors. In the context of independence and objectivity, auditors need to be sceptical and apply suitable safeguards where necessary. Shareholders see auditor independence as an important quality in assessing the reputation and integrity of an auditor. Therefore, auditors must maintain independence to protect their reputation and thereby help them to retain and win audits (ICAEW, 2005). In the perspective of theory of inspired confidence, auditors' job should be executed in such a way that the expectations of a rational outsider are not thwarted. The auditor therefore should do everything reasonable to meet 
public expectation. (Limperg, 1985) whilst the policeman theory perceives the auditor as a policeman focusing on arithmetical accuracy and on prevention of fraud to occur as well as detecting it. (Ghaleb \& Kukreja, 2015). Finally, the credibility theory considers auditors to be a primary function of auditing, the performance of audits will contribute to increasing the credibility of financial statements. The audited financial statement therefore is expected to improve the attitude of the preparers of financial statements as well as reducing the information asymmetry that is taking place between the preparers and the users of financial statements.

Using these theories, Kabiru and Abdullahi (2014), found that Independence of an auditor does significantly improve the quality of audited financial statements of money deposit banks in Nigeria. Compliance to auditing guidelines has positive and significant effect on the quality of audited financial statement of money deposit banks in Nigeria. Material misstatement does significantly affect the quality of audited financial statements of money deposit banks in Nigeria. They also found that audited financial statements of Nigerian money deposit banks, if re-audited by other independent auditors, will give the same result and conclusion.

In his study on factors affecting audit quality in listed manufacturing and commercial services companies in Kenya, Ndisya (2015), established the impact of the independent variables (auditor size, financial status of the company and the logarithm of auditor fees) on the dependent variable (leverage). The dependent variable was audit quality which was represented by leverage as a measure of debt pressure of the companies. Ten manufacturing and commercial services companies listed in the Nairobi stock exchange were used as a sample of the study. The results of analysis indicated that logarithm of audit the fees, financial status of the company, and auditor size were significant in influencing the leverage of the companies and thus audit quality. The size of audit firm had a positive impact on audit quality, while the companies that were struggling financially were more likely to have poor audit quality. The logarithm of audit fees was negatively related with the audit quality. Adeniyi \& Mieseigha (2013), also examined the effect of audit tenure on Audit Quality in Nigeria found that the relationship between tenure and audit quality was observed to be inverse and this could stimulate the discourse on the sensibleness of changing auditors after a period of time as it may be effective at increasing the level of audit quality. For the other variables examined alongside tenure such as board size, board independence and director ownership which are all proxy of the corporate governance were found to be inversely related with audit quality. Their study further reveal that return on assets have also be seen to be in line with prior studies while that of company size is at variance with prior study. Their study disclosed that there is no significant relationship between audit fee and audit quality, there is no significant relationship between audit firm rotation and audit quality also there is no significant relationship between audit firm tenure and audit quality. Also, the auditor compromises his independence most often in a long-term auditor contract and suggests that after all auditor tenure may have significant effect on the audit quality. 


\section{MlMacrothink}

\section{Methodology}

The study employed quantitative technique to examine the relationship between the variables of selected listed companies on the Ghana stock exchange. To obtain an insight about factors influencing audit quality, convenience sampling technique was used for the purpose of the study to obtain the required information from the companies. The sample size for the study was twenty-five (25) listed companies on the Ghana Stock Exchange. (Taro, 1967), n = $\mathrm{N} /(1+<\mathrm{Na}>\wedge 2) \mathrm{N}=33 \mathrm{a}=0.1$

Grounded on secondary data to achieve the research objectives, data was collected from published financial statement and industry survey report. The information gathered covers a period of five years from 2012 to 2017. To effectively measure the relationship between each variable and the influence of those variables on auditor independence and quality, it is necessary to consider the effects of multiple independent variables on audit quality. More specifically, it is suggested that multiple regression analysis is extremely flexible and allows investigating multiple variable relationships in a single analysis context. Statistical Package for Social Sciences (SPSS) was used to analyze data in this study.

Dependent and independent variables

- The dependent variable for the study was Audit quality.

- The independent variables were;

- Audit committee

- Audit firm Size

- $\quad$ Audit fees

Measurement of Variables Table

- Variables Measurement criteria

- Leverage (Total Liabilities)/(Total Assest)

- Audit fees The logarithm of the audit fee.

- Audit firm size

- Dummy variable given 1 if a firm is audited by one of the big four audit firms, and 0 if otherwise.

- Audit committee Dummy variable 1 is given to firms that has audit committees, and 0 if otherwise

\section{Model Specification}

The study investigated the relationship between the three key independent variables of audit quality (audit committee, audit fees and audit firm size) and the dependent variable of audit quality which was proxied by leverage of a company as used by Ndisya (2015). The occurrence of bankruptcy which can be used as direct measure of audit quality is sparse. 


\section{Nl Macrothink}

International Journal of Accounting and Financial Reporting

ISSN 2162-3082

2019, Vol. 9, No. 2

According to Woodland \& Reynolds (2003), bankruptcies can be regarded as a direct measure of the quality of audit. However, the authors argue that bankruptcies are rare occurring audit quality indicators and therefore, leverage ratio was used because it has a very close relationship with bankruptcy as most of the firms facing bankruptcy have significant amount of debts. In this respect, the leverage was used as a proxy for audit quality. Due to the fact that the firms listed on the Ghana stock exchange are audited mandatorily. Therefore, a high leverage ratio can be a clear indicator of low audit quality as it suggests that a company has debt pressure.

Model

$$
\text { Leverage }=\alpha+\beta \_1 \mathrm{AF}+\beta \_2 \mathrm{AC}+\beta \_3 \mathrm{AF}+\varepsilon
$$

Where,

$\mathrm{L}=$ LEVERAGE

$\mathrm{AF}=\mathrm{AUDIT} F E E$

$\mathrm{AC}=\mathrm{AUDIT}$ COMMITTEE

$\mathrm{AF}=\mathrm{AUDIT}$ FIRM SIZE

$\varepsilon=$ MARGIN OF ERROR

$\beta \_1-\beta \_3=$ COEFFICIENTS

\section{Analysis and Discussions of Findings}

\subsection{Descriptive Analysis}

Descriptive statistics were calculated severally so as to provide the basic characteristics of the dataset. Table 1 below shows the descriptive statistics for the two continuous variables (logarithm of auditor remuneration and leverage ratio).

Table 1. Descriptive statistics (quantitative variables)

\begin{tabular}{llllll}
\hline & N & Minimum & Maximum & Mean & Std. Deviation \\
\hline LEVERAGE & 150 & .69 & 99.63 & 66.7738 & 24.22572 \\
\hline AUDIT_COMMITTEE & 150 & .00 & 1.00 & .6800 & .46804 \\
\hline AUDIT_FEE & 150 & 9.21 & 13.59 & 11.5562 & 1.06266 \\
\hline AUDIT_FIRM & 149 & .00 & 1.00 & .7248 & .44811 \\
\hline Valid N (listwise) & 149 & & & & \\
\hline
\end{tabular}

Source: Statistical Package for Social Science (SPSS) 
Table 2. Descriptive statistics ordinal variable (frequency and percentage)

Audit Committee

\begin{tabular}{llllll}
\hline & & Frequency & Percent & Valid Percent & Cumulative Percent \\
\hline Valid & 0 & 48 & 32.0 & 32.0 & 32.0 \\
\cline { 2 - 5 } & 1 & 102 & 68.0 & 68.0 & 100.0 \\
\cline { 2 - 5 } & Total & 150 & 100.0 & 100.0 & \\
\hline
\end{tabular}

Source: Statistical Package for Social Science (SPSS)

The table above shows the distribution of the ordinal variables (audit committee) in terms of frequency and percentage. 1 represents companies with audit committee and 0 represents companies without audit committee. 68 percent of the company sampled had audit committee whiles 32 percent of the company sampled had no audit committee.

Table 3. Descriptive statistics ordinal variable (frequency and percentage)

AUDIT_FIRM

\begin{tabular}{|c|c|c|c|c|c|}
\hline & & Frequency & Percent & Valid Percent & Cumulative Percent \\
\hline \multirow[t]{3}{*}{ Valid } & 0 & 41 & 27.3 & 27.3 & 27.3 \\
\hline & 1 & 109 & 72.7 & 72.7 & 100.0 \\
\hline & Total & 150 & 100.0 & 100.0 & \\
\hline
\end{tabular}

Source: Statistical Package for Social Science (SPSS)

The table above shows the distribution of the ordinal variables (auditor size) in terms of frequency and percentage. 1 represents audit firms in the big four (4) and 0 non-big in the big four. Out of 150 audits performed by these firms, 109 which represents 72.7 percent of the auditing during the study period was done by the big four companies and the remaining 41 representing 27.3 percent was done by non-big four companies.

\subsection{Regression Results}

The model developed in chapter was estimated using the ordinary least squares method.

The model estimated below is in the following form;

$$
\text { Leverage }=\alpha+\beta_{1} A F+\beta_{2} A C+\beta_{3} A F+\varepsilon
$$

Where, 


\section{Ml Macrothink}

International Journal of Accounting and Financial Reporting

Leverage $=$ Total debt $($ both long term and short term) divided by total assets

Audit fees $=$ logarithm of auditor remuneration

Audit committee $=$ A dummy variable for existence of audit committee in the company (takes value " 1 " if the company has an audit committee and the value " 0 " if otherwise)

Audit firm size = A dummy variable the size of the auditing firms (takes value " 1 " if the company is been audited by any of the big four auditing firms and the value " 0 " if otherwise)

$\varepsilon=$ MARGIN OF ERROR

$\beta_{1}-\beta_{3}=$ Co- efficient

$\alpha=$ Constant

Dependent Variable: Leverage

Sample: 2012-2017

Number of Observations $=25$

Table 4. Regression results

\begin{tabular}{llll}
\hline Variables & Co-efficient & P-Value & Actual Sign to Audit Quality \\
\hline AUDIT COMMITTEE & -9.828 & 0.046 & - \\
\hline AUDIT FEE & 12.983 & 0.000 & + \\
\hline AUDIT FIRM & -22.004 & 0.000 & - \\
\hline Number of Companies & 25 & \\
\hline Number of Points & 150 & \\
\hline F-Test(p-value) & 10.925 & \\
\hline Rsquare & 0.583 & \\
\hline
\end{tabular}

Source: Statistical Package for Social Science (SPSS)

\subsection{Model Summary}

The statistical measure $\mathrm{R}$ square shows closeness of fitted data to the regression line. Generally, a better fit of the regression model data is reflected by the R square. 
Table 5. Quantitative variables

\begin{tabular}{|c|c|c|c|}
\hline Model R & R Square & Adjusted R Square & Std. Error of the Estimate \\
\hline $.428^{\mathrm{a}}$ & .583 & .167 & 22.11651 \\
\hline
\end{tabular}

Source: Statistical Package for Social Science (SPSS)

a. Predictors: (Constant), Audit Firm, Audit Committee, Audit Fee

The summary of the model is presented in Table 5. The coefficient of determination (R square) of .583 means that $58.3 \%$ of the audit quality is dependent on the combination of audit firm size, audit fees and audit committee, while the remaining $41.7 \%$ (error term) is traceable to other factors that affect quality of audit, aside the variables specified in the model.

Table 6. ANOVA

\begin{tabular}{lllllll}
\hline \multirow{2}{*}{ Model } & \multicolumn{2}{l}{$\begin{array}{l}\text { Sum } \\
\text { Squares }\end{array}$} & Df & \multicolumn{1}{c}{ Mean } \\
Square & F & Sig. \\
\hline 1 & Regression & 16031.448 & 3 & 5343.816 & 10.925 & $.000^{\mathrm{a}}$ \\
\cline { 2 - 7 } & Residual & 71414.459 & 146 & 489.140 & & \\
\cline { 2 - 7 } & Total & 87445.906 & 149 & & & \\
\hline
\end{tabular}

Source: Statistical Package for Social Science (SPSS)

a. Predictors: (Constant), AUDIT FIRM, AUDIT COMMITTEE, AUDIT FEE

b. Dependent Variable: LEVERAGE

Statistical models ANOVA is used to test significance of all variable and analyses the variance of group mean according to the statistician Ronald Fisher, (Anova, 2002). Table 7 shows the ANOVA results of the model. The F statistics is 10.925, and the $p$ value $\leq .0000$, meaning that the model is statistically significant at $5 \%$ significance level.

Table 7. Regression results coefficients

\begin{tabular}{lllllll}
\hline & & \multicolumn{2}{l}{$\begin{array}{l}\text { Unstandardized } \\
\text { Coefficients }\end{array}$} & \multicolumn{2}{c}{$\begin{array}{l}\text { Standardized } \\
\text { Coefficients }\end{array}$} & \\
\cline { 2 - 5 } Model & B & Std. Error & Beta & T & Sig. \\
\hline 1 & (Constant) & -60.591 & 24.902 & & -2.433 & .016 \\
\cline { 2 - 6 } & AUDIT_COMMITTEE & -9.828 & 4.889 & -.190 & -2.010 & .046 \\
\cline { 2 - 6 } & AUDIT_FEE & 12.983 & 2.412 & .570 & 5.382 & .000 \\
\cline { 2 - 6 } & AUDIT_FIRM & -22.004 & 5.244 & -.406 & -4.196 & .000 \\
\hline
\end{tabular}

Source: Source data 


\section{Mll Macrothink}

International Journal of Accounting and Financial Reporting

ISSN 2162-3082

2019, Vol. 9, No. 2

From the table above, the audit committee, logarithm of audit fee audit firm size are significant in influencing the leverage. This implies that the three independent variables are related to debt pressure that a company has. The presence of auditing committee has a negative relation with leverage. The coefficient for this variable is $\mathbf{- 9 . 8 2 8}$. This implies that the firms that have audit committees have on average leverage ratios that are less by about 9.8\% as compared to firms that do not have an audit committee. This confirms findings of Ndisya (2015) who found a negative relation between audit firm size and audit committee. The less leverage ratio implies less debt pressure. The t-statistic for this variable is -2.010 . Because the absolute value of this t-statistic is greater than 1.96 and 2.56 the coefficient of auditor size is significant at both $5 \%$ and $1 \%$ significance level.

The coefficient of logarithm of fees is also positively related to the leverage ratio at a positive coefficient of 12.983 and it's significant at both $5 \%$ and $1 \%$ level of significance. The t-statistic is greater than 1.96 (at 5\% significance level) and 2.56 (at 1\% significance level). This implies that all other things factors remaining constant, a percentage increase in audit fees would lead to an increase in the leverage by approximately $12.98 \%$. This is logical because high audit fees reduce the ability of companies to repay their debts. In addition due to economic dependence that arises from high audit fees, there can be compromise on quality by the auditor.

The audit firm size was negatively related with leverage at a negative coefficient of -22.004 . This implies that companies that have less debt pressure in several cases were audited by big four (4) auditing firms. This could be attributed to the need to safeguard their credibility and market share by the top four (4) auditing firms (PWC, KPMG, Deloitte and ERNST AND YOUNG). This implies that the firms that are audited by the big FOUR (4) auditing companies (PWC, DELOTTE, KPMG and ERNST \& YOUNG) have on average leverage ratios that are less by about $0.25 \%$ as compared to the firms audited by non-big FOUR (4) auditing firms. The less the leverage ratio the lesser debt pressure. This result confirms the findings by Krishnan and Schauer (2000), Ndisya (2015) and that of Ilaboya et al (2014) who established that there is a negative relationship between audit quality and audit firm size. The $\mathrm{t}$-statistic for this variable is -2.010 because the absolute value of this t-statistic is greater than 1.96 and 2.56 the coefficient of auditor size is significant at both $5 \%$ and $1 \%$ significance level.

\section{Conclusions and Recommendations}

This study sought to establish the factors affecting audit quality in listed firms in Ghana. A cross-sectional approach was used in the analysis in which a linear regression model was used to establish the impact of the independent variables (audit firm size, audit committee and audit fees) on the dependent variable. To normalize the audit fees, its logarithm was taken so as to make the data normal. The independent variable was leverage ratio (total debts divided by total assets of the company). This variable (leverage) was used as a proxy for debt pressure by the companies. In addition, an increase in this variable increases the probabilities of bankruptcy for the companies and therefore it makes it a direct measure of the audit quality. The variable status was a dummy variable which took value of one (1) if the company had 


\section{Mll Macrothink}

International Journal of Accounting and Financial Reporting

ISSN 2162-3082

2019, Vol. 9, No. 2

audit committee in any of the period between 2012 and 2017, and zero (0) otherwise. Also, the auditor size was a dummy variable that took the value of (one) 1 if the auditor was a top four audit company (with respect to The Institute of Chartered Accountants Ghana) and value of zero (0) if otherwise. Twenty-five (25) companies listed at Ghana Stock exchange were used in the study. The results of analysis indicated that logarithm of the fees, audit committee, and auditor size were significant in influencing the leverage of the companies. Because the leverage of the companies can be used as a direct measure of the debt pressure by the companies, the same measure was used as a proxy of audit quality. In this respect therefore, size of auditing firm is positively related with quality of audit while the companies that do not have audit committees are more likely to have poor audit quality as compared to companies that have audit committees. Lastly, an increase in audit fees leads to an increase in costs for companies as well as economic dependence. An increase in costs by companies can lead to an increase in company's debts while economic dependence leads to poor audit quality.

\subsection{Conclusions}

From the research findings, it was therefore concluded that audit fees, audit committee and audit firm size significantly influence the quality of audit. Companies which are struggling were comparably found to have high leverage ratios. This shows that the quality of audit is questionable and also a clear indication of poor audit quality as these companies have been continuously been audited and the issue of high debts had not been raised as a red flag by the auditors. Furthermore, higher audit fee was negatively related with high audit quality. This implies that all other factors remaining unchanged, an increase in audit fee results to an increase in the level of debts by the company. This could be attributed to the economic dependence that arises when the auditing firm receives significant amount of revenue from the client (company). Also, an increase in the audit fees increases the expenses of the company thereby reducing the profits for the company. This leads to an increase in the level of a company's debts. In addition, the high fees charged affect the independence of the auditor thereby negatively affecting the quality of the audit. To conclude, high audit fees charged affect the independence of the auditor thereby negatively affecting the quality of the audit.

\subsection{Recommendations for Policy}

From the study findings, it is evidenced that audit fees, size of the auditing firm and audit committee significantly influence audit quality. Therefore, policy should be based on the three variables. To begin with, there should be regulation of the fees that the auditors charge by the regulators. This is because high audit fees create economic dependence by the auditor. This significantly affects the independence of the auditors which in turn leads to poor audit quality. In this respect fee payable should be established based on factors such as pedigree of the auditor, duration of the audit assignment, and the size of the company, the expertise required for the job. The payment of the adequate and appropriate fee will enable the auditor to do the assurance engagement assignment according to the high degree of standardization expected. Also, there should be high level of professionalism by the audit firms. This means that companies that are highly indebted and has no indication of going concern, but auditors 
fail to detect should be fined or operating license be withdrawn so as to safeguard the shareholders of the companies and also serve as deterrent to other auditing firms.

In addition, the officials of the company who engage in material misstatements of the financial statements should be dismissed of their duties and also be prosecuted.

\subsection{Limitations of the Study}

This study was limited in several ways. First, there is no accurate measure of audit quality and therefore leverage (total debts divided by the total assets of the Company) was used as a proxy for debt pressure by the companies. Due to the low occurrence rates of bankruptcy even among the companies that are struggling financially, debt pressure was used as a measure of financial problems.

Lastly, due to absence of a measure of size of audit firms, a dummy variable had to be used.

\subsection{Suggestions for Further Research}

This study was only focused on listed firms in Ghana. This therefore calls for a similar study but from other countries so as to establish if there are similarities in the findings.

Also, a study about factors that lead to bankruptcies could be conducted. Due to the rare occurrence rate of bankruptcies, companies from various countries that have gone bankrupt can be sampled. After establishing these factors, the report of auditors can be assessed so as to establish whether the identified factors were captured in the auditor's report.

In addition, opinion of financial experts regarding the quality of different areas of auditor's report could be collected by use of questionnaires and then factor analysis carried out to establish the main issues raised by these experts.

Because bankruptcy is usually characterized by a low liquidity position, liquidity position of the company can be used as a direct measure of bankruptcy and hence proxy for audit quality.

\section{References}

Adeniyi, S., \& Mieseigha, E. (2013). Audit Tenure: An Assessment of Audit Quality in Nigeria. International Journal of Academic Research in Accounting, 275-283.

Adeyemi, S., \& Okpala, O. (2011). The Impact of Audit Independence on Financial Reporting: Evidence from Nigeria. Business and Management Review, 9-25.

Arens, A., \& Elder, R. (2012). Mark Bessley-Auditing and Assurance Services (14th ed.). Prentice Hall.

Bartlett, R. (1993). A Scale of Perceived Independence: New Evidence on an old Concept. Accounting, Auditing and Accountability Journal, 15-27.

Briloff, A. (1990). Accountancy and Society.

Cameran, M., Merlotti, E., \& Di Vicenzo, D. (2005). Audit Firm Rotation Rule. SSRN Electronic Journal. 
Collins, A., \& Schultz, N. (1995). A Critical Examination Of Code Of Professional Conducts. Journal of Business Ethics, 31-41.

Creswell, J. (1994). Research Design. Sage Publications, Incorporated.

DeAngelo, E. L. (1981). Auditor Size and Audit Quality. Journal of Accounting and Economics, 183-199.

Deis, D. R., \& Giroux, G. (1992). Determinants of audit quality in the public sector. The Accounting Review, 183-199.

D'Souza, D. (2005). Advanced Auditing. New Delhi: Taxmann Allied Services Pvt Ltd.

GhalebMohammed, A., \& Kukreja, G. D. (2015). Evaluating the Perceptions of Investment Banks on the Effectiveness of Financial Audit Report: Evidence from Kingdom of Bahrain. International Journal of Managerial Studies and Research, 20-27.

Ghosh, A., \& Moon, D. (2005). Auditor Tenure and Perceptions of Audit Quality. The Accountng Review, 585-612.

Grendon, Y., Lam, H., \& Suddaby, R. (2006). The Organisational Context of Professionalism in Accounting. Accounting Organizations and Society, 409-427.

Hussey, R., \& Lan, G. (2010). An Examination of Auditor Independence Issues from the Perspective of UK Finance Directors. Journal of Business Ethics, 169-178.

ICAEW. (2005, December). Agency Theory and the Role of Audit. Audit Quality, 10-12.

Ilaboya, A., \& Ohiokha, F. (2014). Audit firm Characteristics and Audit Quality in Nigeria. International Journal of Business and Economics Research, 187-195.

Jensen, M., \& Meckling, W. (1976). Theory of the firm: Managerial behaviour, agency cost and ownership structure. Journal of Financial Economics, 305-360.

Kabiru, I., \& Abdullahi, S. (2014). An Examination into the Quality of Auditted Finacial Statements of Money Deposits Banks. International Journal of Academic Research in Accounting, 145-156.

Kimberlin C, L., \& Winterstein A, G. (2008). Validity and Reliability of measuerment instrument used in research. AM J Health Syst Pharm, 65(23).

Kothari, C. (2004). Research Methodology. New Age International Publishers.

Lindberg, D., \& Beck, F. (2004). Before and After Enrin: CPA's Views on the Auditor Independce. The CPA Journal, 31-41.

Millichamp, A. (1993). Auditing. London: DP Publications.

Ndisya, A. (2015). Factors Affecting Audit Quality in Listed Manufacturing And Commercial Services Companies in Kenya. Journal of Accounting Literature, 153-193. 


\section{Al Macrothink}

International Journal of Accounting and Financial Reporting

ISSN 2162-3082 2019, Vol. 9, No. 2

Nichols, D., \& Price, K. (1976). The Auditor-firm conflict: an analysis using concepts of exchange theory. The Accounting Review, 335-346.

Nichols, D., \& Price, K. H. (1976). The Auditor - firm conflict: An Analysis Using Concepts of Exchange Theory. The Accounting Review, 335-346.

Raiborn, C., Schorg, C. A., \& Massoud, M. (2006). Should Auditor Rotation be Mandatory?. The Journal of Corporate Accounting and Finance, 37-49.

Tandon, B., Sudhasanam, S., \& Sundharabahu, S. (2000). Practical Auditing. S. CHAND and Co. Ltd.

Taro, Y. (1967). Statistics, An introductory Analysis (2nd ed.). New York, United States of America: Harper and Row press.

Theodore, L. (1985). The Social Responsibility of the Auditor (pp. 1-46).

Vanstraelen, A. (2000). Impact Of Renewable Long Term Audit Mandates On Quality. The European Accounting Review, 416-442.

Vanstraelen, A. (2000). Impact of Renewable Long-term audit mandate on audit Quality. European Accounting Review, 419-442.

Wines, G. (1994). Auditor Independence, Audit qualifications and provision of non-audit service. Accounting and Finance, 34, 75- 86.

Woodland, A., \& Reynolds, J. (2003). Effects of Audit Litigation on Pricing of Audit Services on Selected Nigerian Firms. International Journal of Development and Sustainability, 1503-1527.

\section{Copyright Disclaimer}

Copyright for this article is retained by the author(s), with first publication rights granted to the journal.

This is an open-access article distributed under the terms and conditions of the Creative Commons Attribution license (http://creativecommons.org/licenses/by/4.0/) 